\title{
Pengetahuan dan Perilaku Ibu Rumah Tangga dalam Pengelolaan Sampah Plastik
}

\section{The Level of Housewife's Knowledge and Behavior in Managing Plastic Waste}

\author{
Ririn Setyowati, Surahma Asti Mulasari
}

Fakultas Kesehatan Masyarakat Universitas Ahmad Dahlan Yogyakarta

\begin{abstract}
Abstrak
Pencemaran lingkungan akibat sampah plastik semakin mengkhawatirkan apabila tidak ada usaha untuk mengatasinya. Masyarakat yang kurang pengetahuan dan berperilaku buruk dalam pengelolaan sampah plastik dapat menimbulkan gangguan kesehatan dan lingkungan. Penelitian ini bertujuan mengetahui hubungan antara tingkat pengetahuan ibu rumah tangga dengan perilaku mengelola sampah plastik. Penelitian dilakukan di Dusun Kedesen, Desa Kradenan, Kecamatan Kaliwungu, Kabupaten Semarang Tahun 2012. Penelitian ini menggunakan rancangan studi cross sectional, dengan sampel berjumlah 74 orang yang diambil secara secara acak sederhana. Pengumpulan data dilakukan dengan wawancara terstruktur menggunakan kuesioner. Data dianalisis menggunakan analisis univariat dan analisis bivariat dengan uji statistik Kai Kuadrat $\left(\mathrm{X}^{2}\right)$. Penelitian menemukan sekitar $56,8 \%$ responden berpengetahuan tidak baik dan sekitar $60,8 \%$ responden berperilaku tidak baik. Analisis bivariat menunjukan hubungan yang sangat signifikan antara tingkat pengetahuan ibu rumah tangga dengan perilaku mengelola sampah plastik. Ada hubungan yang sangat signifikan antara tingkat pengetahuan ibu rumah tangga dengan perilaku mengelola sampah plastik di Dusun Kedesen, Desa Kradenan, Kecamatan Kaliwungu, Kabupaten Semarang tahun 2012.
\end{abstract}

Kata kunci: Pengetahuan, perilaku, mengelola sampah plastik

\begin{abstract}
Pollution caused by plastic increase worrying if there is no attempt to resolve it. Lack of knowledge and poor people's behavior in the management of plastic waste can cause environmental and health problems. Management of plastic waste can be started from each household who produce plastic waste. The purpose of this study to determine the relationship between the level of housewife's knowledge with the behavior to manage of plastic waste at Kedesen, Kradenan Village, District Kaliwungu, Semarang in 2012. The study was analytic survey with cross-sectional design. Sample was 74 respondents with simple random sampling. Research tool used was a ques-
\end{abstract}

tionnaire. Analyzed used univariate and bivariate analysis with statistical test Chi Square $\left(X^{2}\right)$. The results showed 74 respondents obtained from 42 respondents (56.8\%) are not well knowledgeable, 32 respondents(43.2\%) both knowledgeable. There were 45 respondents $(60.8 \%)$ did not have good behavior, while 29 respondents (39.2\%) had good behavior. Bivariate analysis showed that there was a significant relationship between the level of knowledge with behavior of housewives in managing plastic waste at the hamlet Kedesen. Statistical results showed the value $(p=0.000)$ smaller than alpha $(\alpha=0.05)$. There was a significant relationship between the level of knowledge with behavior of housewife in managing plastic waste at Kedesen Hamlet, Village Kradenan, Kaliwungudistrict, Semarang regency in 2012.

Keywords: Knowledge, behavior, and managing waste plastics

\section{Pendahuluan}

Derajat kesehatan masyarakat ditentukan oleh kondisi pejamu, agent (penyebab penyakit), dan lingkungan. Faktor lingkungan merupakan unsur penentu kesehatan masyarakat. Apabila terjadi perubahan lingkungan di sekitar manusia, maka akan terjadi perubahan pada kondisi kesehatan lingkungan masyarakat tersebut ${ }^{1}$. Faktor lingkungan dan faktor perilaku sangat berpengaruh terhadap derajat kesehatan masyarakat, sehingga perlu memperoleh perhatian secara sungguh-sungguh. Faktor perilaku sehat diharapkan dapat memelihara, meningkatkan kesehatan dan melindungi diri dari ancaman penyakit, sedangkan lingkungan sehat diharapkan menciptakan lingkungan yang kondusif, bebas polusi, pemukiman

Alamat Korespondensi: Surahmah Asti Mulasari, Ilmu Kesehatan Masyarakat FKM Universitas Ahmad Dahlan Yogyakarta, Jl. Prof. Dr. Soepomo Janturan Yogyakarta 55164, Hp.08164222647,e-mail: rahmasti_fkmuad@yahoo.com 
sehat dan pengelolaan sampah yang sehat. ${ }^{2}$ Dewasa ini, sampah merupakan salah satu masalah serius dalam lingkungan hidup di seluruh dunia dan berhubungan sangat erat dengan kehidupan manusia sehari-hari. Sebagai pihak yang menghasilkan sampah, tidak ada yang dapat terlepas dengan masalah sampah. Dengan demikian, masalah sampah adalah masalah persepsi masyarakat tentang sampah. ${ }^{3}$

Dari segi jumlah dan jenis, sampah menjadi masalah yang semakin hari semakin meningkat sejalan dengan jumlah penduduk, tingkat aktivitas, pola kehidupan, tingkat sosial ekonomi, serta kemajuan teknologi yang semakin bertambah. ${ }^{2,4}$ Salah satu faktor yang menyebabkan kerusakan lingkungan hidup yang sampai kini tetap menjadi masalah besar bagi bangsa Indonesia adalah limbah plastik yang berbahaya dan sulit dikelola. Diperlukan waktu puluhan bahkan ratusan tahun untuk membuat sampah bekas kantong plastik yang banyak diminati oleh masyarakat itu benar-benar terurai. Limbah plastik yang tidak bisa terurai oleh bakteri merupakan masalah yang serius bagi pencemaran tanah. Alangkah baiknya jika limbah plastik tersebut dapat digunakan lagi dengan mendaur ulang dan dijadikan produk baru. Manajemen pengelolaan sampah plastik yang ada saat ini belum berjalan efektif, masih banyak masyarakat yang membuang sampah tampa memperhatikan kategorinya. ${ }^{5}$

Perilaku adalah suatu sikap yang dilahirkan akibat interaksi antara manusia dengan lingkungan, sehingga perilaku individu dan masyarakat dapat mempengaruhi kondisi lingkungan dan kesadaran masyarakat mampu memengaruhi hal tersebut. ${ }^{6}$ Penelitian di Kecamatan Daha menemukan salah satu faktor yang memengaruhi perilaku mengelola sampah adalah tingkat pendidikan dan pengetahuan masyarakat tentang peraturan daerah tentang sampahan. ${ }^{5}$ Sekitar $80 \%$ ibu rumah tangga membuang sampah plastik di kebun sekitar rumah dan membakar sampah plastik di sekitar rumah mereka. Ibu rumah tangga yang sekitar $75 \%$ bekerja sebagai petani sering terlihat membawa bekal minuman memakai botol bekas air mineral. Penelitian ini bertujuan untuk mengetahui hubungan antara tingkat pengetahuan ibu rumah tangga dengan perilaku mengelola sampah plastik.

\section{Metode}

Penelitian ini menggunakan desain studi konservasional cross sectional untuk mengetahui hubungan antara tingkat pengetahuan ibu rumah tangga dengan perilaku mengelola sampah plastik di Dusun Kedesen. Variabel yang diamati dikumpulkan sekali pada waktu yang bersamaan. Penelitian ini dilakukan pada Mei 2012, di Dusun Kedesen, Kelurahan Kradenan, Kecamatan Kaliwungu Semarang. Populasi adalah seluruh Ibu Rumah Tangga di Dusun Kedesen dengan besar sampel
74 ibu rumah tangga dengan kriteria inklusi pendidikan terakhir SD, mempunyai umur 20 - 50 tahun, dan tidak mempunyai pembantu. Penarikan sampel dilakukan dengan metode simple random sampling dengan instrumen kuesioner. Variabel bebas adalah tingkat pengetahuan ibu rumah tangga dan variabel terikat adalah perilaku mengelola sampah plastik, variabel pengganggu adalah sosial ekonomi, pendidikan dan keberadaan pembantu. Metode analisis yang adalah uji Kai Kuadrat dengan tingkat kemaknaan $\mathrm{p}<0,05$.

\section{Hasil}

Kelompok umur 31 - 40 tahun merupakan proporsi tertinggi $(47,2 \%)$, sedangkan distribusi pekerjaan terbesar adalah sebagai petani $(35,1 \%)$, dan wiraswasta $(4,1 \%)$ merupakan yang terkecil. Pendidikan terakhir responden terbanyak adalah SD $(58,1 \%)$ dan pendidikan terakhir perguruan tinggi $(1,4 \%)$ merupakan yang terkecil (Tabel 1). Responden dengan kategori tingkat pengetahuan tidak baik $(56,8 \%)$, sedangkan beperilaku tidak baik $(60,8 \%)$. Terlihat hubungan yang signifikan antara pengetahuan dan perilaku pengelolaan sampah dengan nilai $\mathrm{p}=0,000$ (Tabel 2).

\section{Pembahasan}

Sekitar 58,6\% ibu rumah tangga berpengetahuan pengetahuan tidak baik, pengetahuan yang baik diperoleh dari berbagai sumber seperti pengalaman ibu rumah tangga, serta yang diperoleh melalui media cetak, radio dan televisi yang berpengaruh besar dalam pembentukan opini dan kepercayaan. ${ }^{7}$ Informasi baru tentang sesuatu memberikan landasan kognitif bagi peningkatan pengetahuan. ${ }^{8}$ Di Dusun Kedesen, tingkat pengetahuan ibu rumah tangga tergolong rendah. Pengetahuan tentang sampah yang tidak baik antara lain dipengaruhi oleh informasi dan kegiatan penyuluhan kepada masyarakat yang kurang. Hal tersebut diduga disebabkan oleh kegiatan penyuluhan di Dusun Kedesen lebih terfokus pada penyuluhan kesehatan seperti penyakit demam berdarah, malaria, flu burung, polio,

Tabel 1. Karakteristik Responden

\begin{tabular}{llll}
\hline Variabel & Kategori & $\mathbf{n}$ & $\%$ \\
\hline Usia (tahun) & $20-30$ & 14 & 18,9 \\
& $31-40$ & 35 & 47,2 \\
Pekerjaan & $41-50$ & 25 & 33,7 \\
& Ibu rumah tangga & 18 & 24,3 \\
& Petani & 26 & 35,1 \\
& Pedagang & 16 & 21,6 \\
Pendidikan Terakhir & Wiraswasta & 3 & 4,1 \\
& Buruh & 11 & 14,8 \\
& SD & 43 & 58,1 \\
& SMP & 8 & 10,8 \\
& SMA & 22 & 29,7 \\
& Perguruan tinggi & 1 & 1,4 \\
\hline
\end{tabular}


Tabel 2. Hubungan Tingkat Pengetahuan Ibu Rumah Tangga dengan Perilaku Mengelola Sampah

\begin{tabular}{lllllllll}
\hline & \multicolumn{9}{c}{ Perilaku } & \\
\cline { 2 - 6 } Pengetahuan & \multicolumn{2}{c}{ Baik } & \multicolumn{2}{c}{ Tidak Baik } & \multicolumn{2}{c}{ Total } & \multirow{2}{*}{ Nilai p } \\
\cline { 2 - 7 } & $\mathbf{n}$ & $\%$ & $\mathbf{n}$ & $\%$ & $\mathbf{n}$ & $\%$ & \\
\cline { 2 - 7 } Baik & 20 & 27,0 & 12 & 16,2 & 32 & 43,2 & \\
Tidak baik & 9 & 12,2 & 33 & 44,6 & 42 & 56,8 & 0,000 \\
Total & 29 & 39,2 & 45 & 60,8 & 74 & 100 & \\
\hline
\end{tabular}

tetapi masih sangat minim penyuluhan tentang dampak berbahaya sampah yang tidak dikelola dengan baik. Hal tersebut berakibat kepada kesadaran mengelola sampah plastik yang rendah. Pengetahuan masyarakat tentang bahaya sampah plastik perlu diberikan karena potensi bahaya sampah plastik ini sangat besar. Sementara, dalam kehidupan sehari-hari ibu rumah tangga tidak mungkin terlepas dari penggunaan sampah plastik.

Sampah plastik berbahaya karena sulit didegradasi, plastik sulit terurai dalam tanah karena membutuhkan waktu sampai 100 tahun atau lebih. Pemakaian sampah plastik mencemari tanah, air tanah, dan makhluk di bawah tanah. Racun-racun partikel plastik tersebut masuk ke dalam tanah dan dapat membunuh hewan atau bakteri pengurai di dalam tanah. Plastik mengganggu jalur air yang teresap dalam tanah dan menurunkan kesuburan tanah karena menghalangi sirkulasi udara dalam tanah dan ruang gerak makhluk yang berperan menyuburkan tanah. Sampah plastik merupakan gangguan serius bagi kelestarian lingkungan hidup. ${ }^{9}$

Peningkatan pengetahuan dapat dilakukan dengan pedidikan formal ataupun informal, di kalangan masyarakat, peningkatan pendidikan dilakukan secara informal dengan sosialisasi ke masyarakat, penyuluhan, penyebaran media promosi kesehatan berupa poster dan selebaran. Upaya pemberdayaan masyarakat dimulai dari meningkatkan pemahaman masyarakat tentang kegiatan yang akan dilakukan, termasuk pengelolaan sampah plastik.

Upaya peningkatan kualitas lingkungan hidup yang paling efektif dilakukan dengan promosi pada setiap saat sehingga perlu media khusus. ${ }^{10}$ Pemberdayaan masyarakat dalam mengelola sampah dimulai dengan sosialisasi dan pemahaman tentang penanggulangan masalah sampah. ${ }^{11}$ Sesudah pelatihan, pengetahuan responden sebagian besar menjadi baik $(86,7 \%)$, menunjukkan peningkatan pengetahuan. Pelatihan berpengaruh meningkatkan pengetahuan ibu PKK dalam mengelola sampah, dan pengetahuan berpengaruh terhadap pengelolaan sampah dalam kehidupan sehari-hari. ${ }^{12}$ Sosialisasi pengolahan sampah dapat pula dilakukan dengan penjelasan dan diskusi kelompok, studi banding, membaca dari selebaran ataupun makalah. ${ }^{13}$ Penyuluhan sangat penting bagi masyarakat sebagai sarana sosialisasi sehingga mereka bersedia untuk berpartisipasi dan berperilaku mengolah sampah sesuai ketentuan/kaidah yang berlaku. ${ }^{14}$ Melalui penyuluhan masyarakat menerima gagasan pengolahan sampah dengan baik. Hal tersebut penting dan bermanfaat bagi lingkungan dan bagi diri mereka sendiri. ${ }^{15}$

Sekitar 39,2\% responden mempunyai perilaku yang baik yang mengindikasikan bahwa ibu rumah tangga tersebut berusaha mengaplikasikan pengetahuan yang mereka miliki ke dalam perilaku sehari-hari. Sebagian besar ibu rumah tangga $(60,8 \%)$ mempunyai perilaku tidak baik, yang menunjukkan bahwa kurang kesadaran dalam diri mereka untuk berperilaku sehat. Pendidikan kesehatan yang diberikan kepada masyarakat sangat kurang sehingga memengaruhi perilaku. Pendidikan kesehatan berfungsi sebagai media atau sarana menyediakan kondisi sosiopsikologis sedemikian rupa sehingga individu atau masyarakat berperilaku sesuai dengan norma-norma hidup sehat. ${ }^{12}$ Ada beberapa ibu rumah tangga yang mempunyai pengetahuan kurang, tetapi berusaha mengaplikasikan pengetahuan terbatas yang mereka miliki dalam kehidupan sehari-hari. Kemungkinan lain, kelompok tersebut melakukan pengolahan sampah, walaupun pengetahuan rendah, karena sudah terbiasa sejak kecil atau budaya yang ditrapkan dalam keluarga tanpa mengetahui hakikat perilaku tersebut. Sebaliknya, ibu yang mempunyai pengetahuan baik tetapi berperilaku tidak baik karena belum mampu mengaplikasikan pengetahuan dalam mengelola sampah plastik. Responden tersebut belum mampu memberikan dorongan terhadap perilaku mengelola sampah plastik secara benar. Kesadaran pada kebersihan lingkungan merupakan faktor pendorong terealisasi perilaku baik mengelola sampah. Tanpa kesadaran, pengetahuan baik tidak mendorong penerapan pengolahan sampah dengan baik.

Sebagian besar ibu rumah tangga mempunyai pengetahuan dan perilaku yang tidak baik. Hal tersebut disebabkan oleh penyuluhan tentang sampah plastik masih rendah, penyuluhan kesehatan yang berdampak kesehatan langsung seperti penyuluhan flu burung, flu babi, polio, DBD, dan malaria lebih diprioritaskan. Pengetahuan dan pendidikan akan mengubah sikap dan pola pikir seseorang dalam bertindak, tanpa pengetahuan seseorang lebih mudah bertindak salah dibandingkan dengan tindakan yang berdasarkan pengetahuan yang dimiliki. Ilmu pengetahuan meminimalisasi kesalahan dalam praktik dan tindakan. Perilaku yang didasarkan kepada ilmu pengetahuan lebih bertahan lama dan pada akhirnya menjadi kebiasaan karena mengetahui dengan pasti manfaat, kekurangan, dan kelemahan dari tindakan yang dilakukan. Seseorang akan bertindak hati-hati dan waspada apabila sebelumnya telah mengetahui risiko tindakan yang dilakukan.

Pengalaman membuktikan bahwa perilaku yang di- 
dasari oleh pengetahuan lebih langgeng daripada yang tidak didasari pengetahuan. Perilaku yang baik juga menunjukkan kesadaran ibu rumah tangga dalam mengelola lingkungan sehingga tidak mengganggu kesehatan diri, keluarga dan masyarakat. ${ }^{15}$ Perilaku masyarakat dalam mengelola sampah yang buruk juga ditemukan di Kota Tembilah. Mereka masih banyak yang belum memanfaatkan tempat pembuangan sampah, bahkan masih banyak yang membuang sampah ke parit atau sungai. Hal ini mengindikasikan pengetahuan masyarakat yang rendah tentang pengelolaan sampah. ${ }^{14}$ Masyarakat Dusun Dukuh Godean mempunyai perilaku tidak baik mengolah sampah, masih sedikit masyarakat yang sadar mengolah sampah sendiri. Pengolahan sampah masih dalam kegiatan memilah sampah yang memisahkan sampah basah dan sampah kering, dan memanfaatkan lagi barang-barang yang masih layak pakai untuk dijual. Banyak masyarakat yang mengerti cara pengolahan sampah, tetapi keinginan mengolah sampah yang baik belum dilakukan secara penuh. ${ }^{16}$ Peran serta masyarakat Kecamatan Klungkung dalam pengelolaan sampah cukup baik yang oleh keberadaan beberapa komunitas yang dengan inisiatif sendiri melakukan pengelolaan sampah berkonsep 3R di lingkungan rumah warga. Sekitar 45,28\% warga melakukan pemilahan sampah di rumah dan $100 \%$ warga menyatakan bersedia melakukan pemilahan sampah di rumah. Perencanaan pengelolaan sampah yang terpadu dengan konsep 3R perlu dilakukan. ${ }^{17}$

Perilaku yang kurang baik dalam mengelola sampah plastik tersebut terjadi karena rendahnya kesadaran mengelola sampah plastik yang semakin hari semakin banyak digunakan. Selain itu, tempat sampah untuk pemilahan jenis plastik tidak tersedia di setiap rumah karena kebiasaan masyarakat membuang sampah plastik di kebun dan kebiasaan membakar sampah plastik di sekitar rumah. Ketersediaan fasilitas tempat sampah merupakan langkah awal untuk pemilahan sampah plastik berhubungan dengan praktik perilaku hidup sehat.

Tanpa kesedaran setiap anggota keluarga untuk mengelola sampah plastik dengan pemilahan sebagai langkah awal mendaur ulang, menggunakan kembali sampah plastik sehingga mengurangi penggunaan sampah plastik maka akan berakibat kerusakan lingkungan seperti kerusakan lingkungan dan air tanah. Dalam jangka panjang, asap hasil pembakaran sampah plastik juga mengganggu kesehatan, racun yang terakumulasi di dalam tubuh akan menimbulkan gangguan kesehatan seperti kanker, kerusakan hormon, dan cacat janin. Selain itu, pada musim penghujan sampah plastik yang dibuang sembarangan di lingkungan sekitar membentuk cekungan dan terisi air hujan, menyebabkan sumber penyakit, akibat perkembangbiakan nyamuk vektor DBD dan malaria.

Pengetahuan tidak selalu berkontribusi positif terhadap perubahan perilaku seseorang sehingga pengetahuan yang baik belum tentu menjamin perilaku yang baik. ${ }^{8}$ Beberapa responden yang berpengetahuan baik dan berperilaku baik, berusaha mengaplikasikan pengetahuan ke dalam kehidupan sehari-hari. Perilaku manusia merupakan hasil dari berbagai pengalaman dan interaksi manusia dengan lingkungan yang terwujud dalam bentuk pengetahuan, sikap, dan tindakan. Responden yang mempunyai pengetahuan tentang sampah plastik mengupayakan agar keadaan rumah mereka dapat terbebas dari gangguan lingkungan dan kesehatan akibat sampah. Informasi dapat memengaruhi pengetahuan seseorang sehingga sumber informasi dapat menstimulasi pengetahuan tentang sampah plastik. Dalam menerima informasi, responden mempunyai persepsi yang berbedabeda sehingga ber-pengaruh terhadap tingkatan pengetahuan yang didapatkan. ${ }^{18}$

Hubungan yang bermakna didapatkan antara pengetahuan ibu rumah tangga dengan perilaku mengelola sampah plastik. Pengetahuan ibu rumah tangga dan perilaku mengelola sampah plastik berhubungan secara bermakna dengan nilai $p=0,000(p<0,05)$. Penelitian di Kecamatan Daha menemukan bahwa pengetahuan berpengaruh terhadap perilaku masyarakat dalam mengelola sampah. ${ }^{7}$ Perilaku masyarakat dan peran serta pemerintah daerah dalam pengelolaan sampah di Kota Tembilahan menunjukkan hubungan yang sangat erat antara perilaku masyarakat dengan pengelolaan sampah. Perilaku masyarakat semakin baik berhubungan dengan tingkat pengelolaan sampah yang semakin baik pula. ${ }^{14}$ Pengamatan terhadap masyarakat mendapatkan gambaran bahwa valensi tindakan individual berperan bermakna dalam menentukan perbedaan kualitas kebersihan lokasi. Berbagai tindakan individual yang bervalensi negatif seperti membuang sampah sembarangan dalam kehidupan keseharian di suatu wilayah cenderung mengotori lingkungan. Sebaliknya, hanya tindakan-tindakan yang bervalensi positif yang berpotensi dan mampu menciptakan kondisi bersih. ${ }^{18}$ Perilaku seseorang dalam kehidupan sehari-hari memengaruhi perilaku mengelola sampah. ${ }^{19}$

Hasil penelitian serupa ditemukan pada pedagang sayur di pasar. Pengetahuan tentang kebersihan lingkungan berhubungan positif dengan pengelolaan sampah dan lingkungan hidup pedagang sayur. Semakin baik pengetahuan semakin baik pula perilaku mengelola lingkungan. ${ }^{20}$ Pengetahuan yang baik berpengaruh pada perilaku yang baik dan sebaliknya pengetahuan yang tidak baik berpengaruh tidak baik pula pada perilaku, seperti yang terjadi pada ibu-ibu rumah tangga di Dusun Kedesen, Desa Kradenan, Kecamatan Kaliwungu, Kabupaten Semarang. Hal tersebut berbeda dengan hasil penelitian 
di Godean bahwa tidak semua responden yang mempunyai pengetahuan yang baik mempunyai sikap dan perilaku yang baik dalam mengelola sampah. Tidak terdapat hubungan yang bermakna antara pengetahuan dan perilaku mengelola sampah. Sikap masyarakat yang kurang baik ini kemungkinan dipengaruhi oleh tingkat pengetahuan dan kematangan usia. Sebagian besar responden yang menyatakan tidak setuju terhadap pengolahan sampah tersebut dipengaruhi oleh ketiadaan sarana dan prasarana pengangkutan sampah sehingga mereka membakar sampah dan sebagian yang lain membuang sampah di tempat pembuangan sampah di sekitar wilayah pasar. ${ }^{16}$

\section{Kesimpulan}

Sekitar 56,8\% ibu rumah tangga di Dusun Kedesen, Desa Kradenan, Kecamatan Kaliwungu, Kabupaten Semarang memiliki pengetahuan yang baik dalam mengelola sampah. Sebanyak $60,8 \%$ ibu rumah tangga berperilaku tidak baik dan 39,2\% berperilaku baik. Dari hasil tersebut, dapat disimpulkan bahwa terdapat hubungan yang sangat signifikan antara tingkat pengetahuan ibu rumah tangga dengan perilaku mengelola sampah plastik (nilai $\mathrm{p}=0,000$ ).

\section{Saran}

Kader kesehatan disarankan meningkatkan peran dalam memberikan pemahaman kepada masyarakat tentang kepentingan pengelolaan sampah plastik secara sederhana dan benar, serta menfaat yang positif, melalui posyandu, pertemuan kader, arisan PKK, pengajian ibuibu, dan lain-lain. Dinas kesehatan disarankan untuk meningkatkan pemahaman tentang pengelolaan sampah plastik secara benar melalui media elektronik dan media massa, serta lebih meningkatkan kesadaran masyarakat untuk menjaga kebersihan lingkungan tempat tinggal melalui penyuluhan dan pelatihan kader kesehatan.

\section{Daftar Pustaka}

1. Mukono HJ. Prinsip dasar kesehatan lingkungan. Edisi Kedua. Surabaya: Airlangga University Press; 2006.

2. Azkha N. Analisis timbulan, komposisi, dan karakteristik sampah di Kota Padang. Jurnal Kesehatan Masyarakat. 2006; 1(1): 14-8.

3. Dwiyanto BM. Model peningkatan partisipasi masyarakat dan penguatan sinergi dalam pengelolaan sampah perkotaan. Jurnal Ekonomi
Pembangunan. 2011; 12(2): 239-56.

4. Suprapto. Dampak masalah sampah terhadap kesehatan masyarakat. Jurnal Mutiara KesehatanIndonesia. 2005; 1(2): 1-4.

5. Firdaus, Tjitro S. Studi eksperimental pengaruh paramater proses pencetakan bahan plastik terhadap cacat penyusutan (Shrinkage) pada benda cetak pneumatics holder. Jurnal Teknik Mesin Fakultas Teknologi Industri Universitas Kristen Petra. 2002; 4(2): 75-80.

6. Widodo T. Studi tentang peranan unit pasar dalam pengelolaan sampah di Pasar Merdeka Kota Samarinda. Journal Administrasi Negara. 2013; 1(1): 1-11.

7. Riswan, Sunoko HR, Hadiyarto A. Pengelolaan sampah rumah tangga di Kecamatan Daha Selatan. Jurnal Ilmu Lingkungan. 2011; 9(1): 31-39.

8. Azwar. Sikap manusia teori dan pengukurannya. Yogyakarta: Pustaka Pelajar; 2011.

9. Hardiatmi S. Pendukung keberhasilan pengelolaan sampah kota. Jurnal Inovasi Pertanian. 2011; 10(1): 50-66.

10. Kumurur VA. Pengetahuan, sikap, dan kepedulian mahasiswa pascasarjana ilmu lingkungan terhadap lingkungan hidup Kota Jakarta. EKOTON. 2008; 8(2): 1-24.

11. Suartika IG. Penanganan sampah secara swadaya di Desa Pakraman Celuk, Sukawati, Gianyar. Jurnal Bumi Lestari. 2001; 11(2): 379-86.

12. Salawati T, Astuti R, Hayati RN. Pengaruh program pelatihan pengolahan sampah padat organik menggunakan metode composting terhadap pengetahuan dan keterampilan ibu-ibu PKK di RW III Kelurahan Boja Kabupaten Kendal. Jurnal Promosi Kesehatan Indonesia. 2008; 3(2): 63-73.

13. Mohamad F, Sutra DC, Kusnawati E. Pemberdayaan masyarakat dalam pengelolaan sampah di Dukuh Mrican Sleman Yogyakarta. Jurnal Health and Sport. 2012; 5(3): 695-706.

14. Mulyadi A, Husein S, Saam Z. Perilaku masyarakat dan peran serta Pemerintah Daerah Dalam Pengelolaan Sampah di Kota Tembilah. Ilmu Lingkungan. Jurnal Enveronmental Science. 2010; 2(3): 147-62.

15. Notoadmodjo S. Promosi kesehatan dan ilmu perilaku. Jakarta: Rineka Cipta; 2007.

16. Mulasari SA. Hubungan tingkat pengetahuan dan sikap terhadap perilaku masyarakat dalam mengelola sampah di Dusun Padukuhan Desa Sidokarto Kecamatan Godean Kabupaten Sleman Yogyakarta. Jurnal Kesmas Fakultas Kesehatan Masyarakat Universitas Ahmad Dahlan. 2012; 6(3): 204-11.

17. Yasa IMT, Surayasa N. Studi evaluasi pengelolaan sampah dengan konsep 3R (studi kasus: Kecamatan Klungkung, Kabupaten Klungkung). Wicaksana. Jurnal Lingkungan. 2012; 21(1): 1-5.

18. Wibowo I. Pola perilaku kebersihan: studi psikologi lingkungan tentang penanggulangan sampah perkotaan. MAKARA Sosial Humaniora. 2009; 13(1): 37-47. 